Tohoku J. exp. Med., 1971, 103, 231-245

\title{
Sucking Ability of Newborns
}

\author{
SeIJi NagaI \\ Department of Obstetrics and Gynecology, Tohoku University \\ School of Medicine, Sendai \\ Chisato Yamada \\ Department of Obstetrics and Gynecology, National Sendai \\ Hospital, Sendai
}

NAGAI, S. Sucking Ability of Newborns. Tohoku J. exp. Med., 1971, 103, (3), 231-245. - The sucking ability of newborns was measured using an electronic manometer and analyzed for the following parameters: 1) sucking rate, 2) intraoral pressure, 3) continuous sucking time, 4) sucking time, and 5) actual sucking time. These five parameters were essentially the same among the normal newborns and it was also indicated that in the normal newborns, any difference was not exhibited by different feeding methods. The results also suggested that sucking was first of all an adequate stimulus of newborns to the mother's nipples. The sucking time was prolonged significantly in the newborns whose intraoral pressure during sucking maintained positive or alternately positive-negative for a while, but this prolongation was not recognizable on the 7 th day of birth. The respiratory rate during sucking did not differ significantly from that immediately before or after sucking. sucking ability; newborns

Recently, the tendency toward increase in artificial feeding has been noted and much discussed. Mayer (1958) reported that the percentage of infants in the United Sates who were admitted to the hospital maternity nurseries and were breast-fed decreased from $38 \%$ in 1946 to $21 \%$ in 1956, while artificial feeding increased from $35 \%$ to $63 \%$. It is evident that breast-feeding is the most suitable nutritional method for newborns. On the other hand, the quality and the production technique of artificial milk have been improved remarkably, so that the disparity between the breast milk and artificial milk has been considerably reduced. It may become possible in the future to produce an artificial milk of excellent quality which is nutritionally equal to breast milk. However, we still have to resort to some artificial feeding, which is different from natural one. Accordingly, it is important to devise the most ideal feeding method like breast feeding, when artificial milk is used.

Beintema (1968) reported that in mammals the days required for the young to reach two times the birth weight differ markedly in different species. Bartram (1959) described in his book that no mammal would lactate the young of another species. It is likely that there is some species difference in the properties of millk of

Received for publication, April 2, 1970. 
mammals. It is generally thought that in mammals, lactation is an act based on species-preservation for the mother, and sucking is an act of self-preservation of the young.

In human beings, civilization influences various acts of human instinct, and they change the instinct so as to adapt themselves to the social conditions. This makes human lactation a rather complex problem. In the present paper, the pattern of sucking is described in relation to different feeding methods in newborns, who have apparently the ability of spontaneous sucking.

\section{Materials and Methods}

The subjects were selected according to certain diagnostic standards from the newborns born at the Obstetrical Unit of the National Sendai Hospital. The sucking ability of newborns was measured as follows; A nursing-bottle was filled with $20 \mathrm{ml}$ of artificial milk and fitted with a rubber nipple. A hole (1.8\%) was made by a nipple puncture (Pigeon K.K.) on the lateral side $5 \mathrm{~mm}$ apart from the tip. A polyethylene tube $(2 \mathrm{~mm}$ in inner diameter) was inserted to the nipple from the lower lateral side toward the tip and the tube was projected $2 \mathrm{~mm}$ from the tip of the nipple. The other end of the tube was connected with an electronic manometer MP-47 (Nihon Koden K.K.).

The cyclic fluctuation of intraoral pressure was recorded by using a multipurpose polygraph (Nihon Koden K.K.). Respiratory rate was also measured in a group of experimental newborns using a thermister stuck into the naris. All the experiments were performed more than three hours after the last lactation,

The following five parameters of sucking were investigated: 1) the sucking rate as observed over a period of 10 seconds, i.e., from 5 seconds till 15 seconds after the beginning of sucking, 2) the average levels of intraoral pressure during sucking in the same period of time, 3) the time from the beginning of sucking until the first interruption of sucking (the continuous sucking time), 4) the time necessary for the newborns to suck all the milk in the nursing-bottle (the sucking time), and 5) the time actually consumed for sucking during drinking $20 \mathrm{ml}$ of milk (the actual sucking time).

\section{Results}

The sucking rate and intraoral pressure were measured in newborns from the 2nd day of birth until the 6th day for a period from 5 seconds till 180 seconds after beginning of sucking. The results obtained were shown in Fig. 1. The levels of intraoral pressure tended to decrease with the lapse of time, but they are restored more or less from 120 seconds on. The sucking rates also tended to decrease, but afterward it maintained a steady level. No particular relation could be observed between either of these two factors and the day after birth.

The mentioned five parameters for the mature newborns with spontaneous delivery were shown in Table 1. The sucking rate did not change from the first day till the 7th day of birth. The intraoral pressure increased significantly within one day after birth $(0.001<p<0.01)$, but afterwards the pressure did not change significantly until the 7 th day. The pressure on the 7 th day was significantly higher than that on the first day $(p<0.001)$, but there was no statistically significant difference between the levels of pressure on the 2 nd and 7 th days. The continuous 

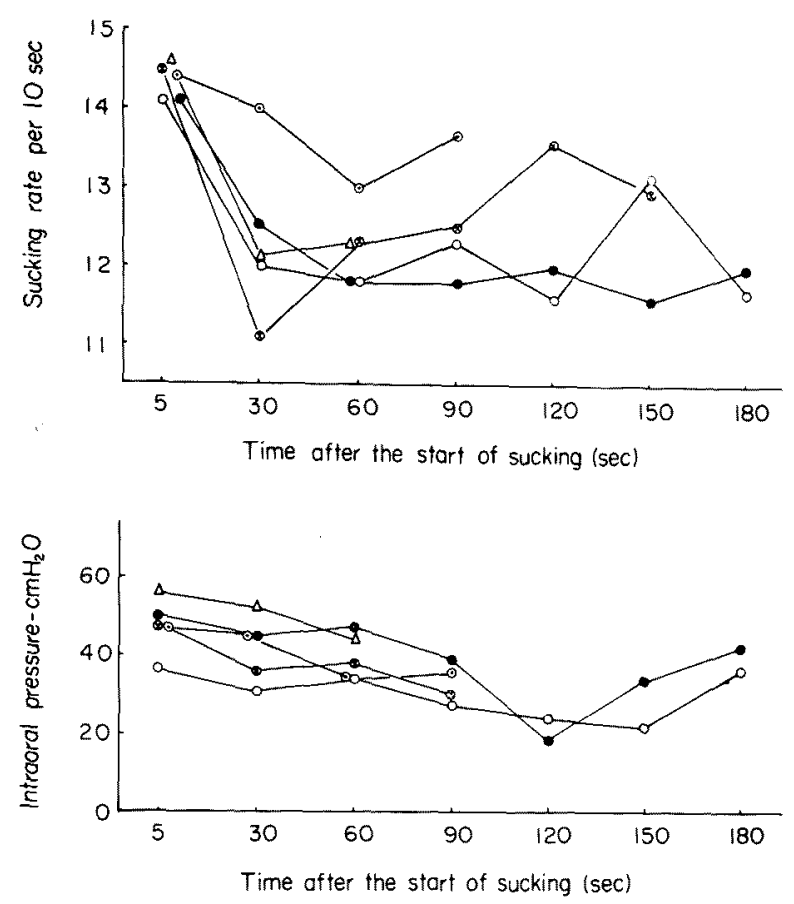

Fig. 1. Sucking rate and intraoral pressure of the newborns from the 2 nd day until the 6 th day after birth.

- 2 2nd day, mean rate or level of 4-6 cases.

3rd day, mean rate or level of 3-6 cases.

- 4th day, mean rate or level of 3-6 cases.

$\multimap 5$ th day, mean rate or level of 6 cases.

$\triangle{ }_{\triangle} 6$ th day, mean rate or level of $3-5$ cases.

TABLE 1 Sucking ability on the 1st to 7th days of birth in mature newborns of full-term spontaneous delivery

\begin{tabular}{|c|c|c|c|c|c|c|c|}
\hline Sucking ability & 1st day & 2nd day & 3rd day & 4th day & 5th day & 6th day & 7th day \\
\hline $\begin{array}{l}\text { Sucking rate/ } \\
10 \mathrm{sec}\end{array}$ & 9.6 $6^{*} \pm 4.1$ & $\begin{array}{c}12.4 \pm 2.8 \\
17\end{array}$ & $\begin{array}{c}13.8 \pm 1.6 \\
22\end{array}$ & $\begin{array}{c}12.6 \pm 1.7 \\
17\end{array}$ & $\begin{array}{c}\text { 13. } 7 \pm 1.5 \\
20\end{array}$ & $\begin{array}{c}13.7 \pm 1.9 \\
21\end{array}$ & $\begin{array}{c}13.8 \pm 1.5 \\
15\end{array}$ \\
\hline $\begin{array}{l}\text { Intraoral pressure } \\
\left(-\mathrm{cm} \mathrm{H}_{2} \mathrm{O}\right)\end{array}$ & $\begin{array}{c}21 \pm 14 \\
10\end{array}$ & $\begin{array}{c}40 \pm 20 \\
11\end{array}$ & $\begin{array}{c}40 \pm 14 \\
22\end{array}$ & $\begin{array}{c}49 \pm 17 \\
16\end{array}$ & $\begin{array}{c}45 \pm 19 \\
15\end{array}$ & $\begin{array}{l}42 \pm 16 \\
21\end{array}$ & $\begin{array}{c}52 \pm 16 \\
14\end{array}$ \\
\hline $\begin{array}{l}\text { Continuous suck- } \\
\text { ing time (sec) }\end{array}$ & & $\begin{array}{c}103 \pm 74 \\
11\end{array}$ & $\begin{array}{c}173 \pm 59 \\
11\end{array}$ & $\begin{array}{c}88 \pm 72 \\
15\end{array}$ & $\begin{array}{c}83 \pm 38 \\
12\end{array}$ & $\begin{array}{c}10 \pm \pm 60 \\
20\end{array}$ & $\begin{array}{c}84 \pm 56 \\
14\end{array}$ \\
\hline $\begin{array}{l}\text { Sucking time } \\
\text { (sec) }\end{array}$ & & $\begin{array}{c}263 \pm 96 \\
11\end{array}$ & $\begin{array}{c}210 \pm 93 \\
11\end{array}$ & $\begin{array}{c}288 \pm 188 \\
15\end{array}$ & $\begin{array}{c}193 \pm 138 \\
12\end{array}$ & $\begin{array}{c}224 \pm 143 \\
20\end{array}$ & $\begin{array}{c}234 \pm 145 \\
14\end{array}$ \\
\hline $\begin{array}{l}\text { Actual sucking } \\
\text { time (sec) }\end{array}$ & & $\begin{array}{c}220 \pm 90 \\
11\end{array}$ & $\begin{array}{c}190 \pm 61 \\
11\end{array}$ & $\begin{array}{c}206 \pm 107 \\
15\end{array}$ & $\begin{array}{c}154 \pm 92 \\
12\end{array}$ & $\begin{array}{c}201 \pm 114 \\
20\end{array}$ & $\begin{array}{c}187 \pm 104 \\
14\end{array}$ \\
\hline
\end{tabular}


sucking time on the 3rd day was significantly longer than these on the 2nd and 4th days $(0.02<p<0.05, p<0.011)$, but afterwards it did not fluctuate markedly; both the sucking time and actual sucking time were nearly constant from the 2nd till the 7 th days. Nor was any significant difference observed between the 2nd and the 7 th days with respect to these three time components.

According to the sucking method on the 6th day, the newborns were divided into three groups, i.e., breast-feeding group, mixed feeding group and artificial feeding group, and the five parameters of sucking ability in the mixed and artificial

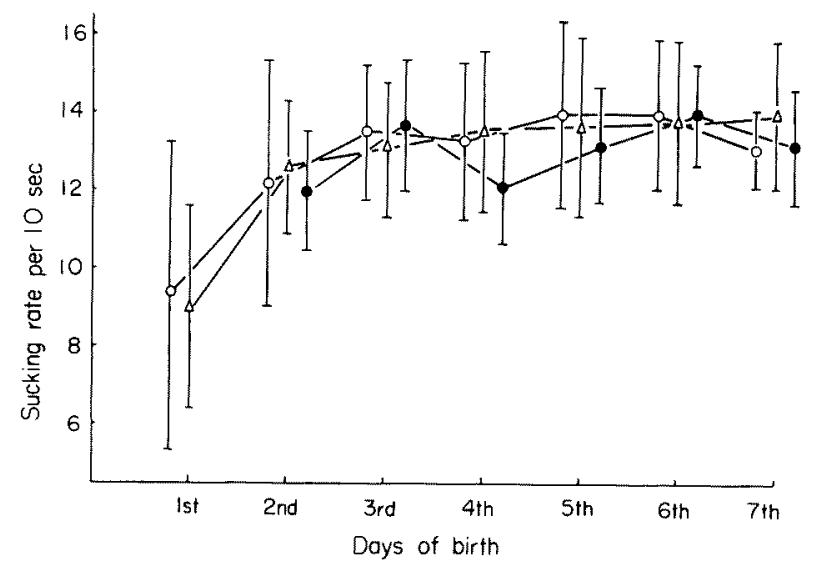

\begin{tabular}{c|c|c|c|c|c|c|c|c}
\hline $\begin{array}{c}\text { Number } \\
\text { of }\end{array}$ & 0 & 12 & 18 & 19 & 16 & 14 & 16 & 6 \\
\hline $\begin{array}{c}\text { cases } \\
\text { of }\end{array}$ & - & & 18 & 16 & 13 & 16 & 19 & 12 \\
\hline
\end{tabular}

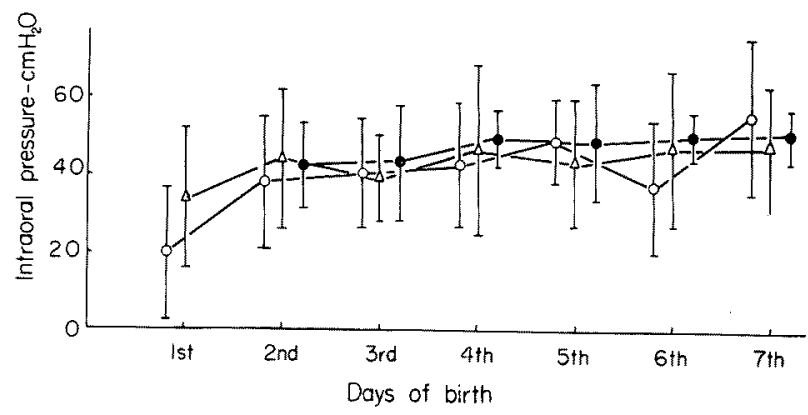

\begin{tabular}{c|c|c|c|c|c|c|c|c}
\hline $\begin{array}{c}\text { Number } \\
\text { of }\end{array}$ & 0 & 13 & 17 & 19 & 15 & 14 & 16 & 6 \\
\hline \begin{tabular}{c} 
cases \\
\cline { 2 - 6 }
\end{tabular} & - & 7 & 17 & 16 & 13 & 16 & 20 & 11 \\
\hline
\end{tabular}

Fig. 2. Sucking rate and intraoral pressure of the breast, mixed and artificial feeding newborns.

- Breast feeding. $\triangle$ Mixed feeding. - Artificial feeding. 
TABLE 2. Continuous sucking time, sucking time and actual sucking time of newborns with breast, mixed and artificial feeding

\begin{tabular}{|c|c|c|c|c|c|c|c|}
\hline & Feeding & 2nd day & $3 \mathrm{rd}$ day & 4th day & 5th day & 6th day & 7th day \\
\hline$\widehat{\overparen{g}}$ & Breast feeding & $\begin{array}{c}102 \pm 51^{*} \\
10 \dagger\end{array}$ & $\begin{array}{c}96 \pm 66 \\
11\end{array}$ & $\begin{array}{c}109 \pm 64 \\
14\end{array}$ & $\begin{array}{c}103 \pm 57 \\
12\end{array}$ & $\begin{array}{c}95 \pm 65 \\
15\end{array}$ & $\begin{array}{c}66 \pm 52 \\
6\end{array}$ \\
\hline 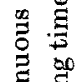 & Mixed feeding & $\begin{array}{c}61 \pm 35 \\
14\end{array}$ & $\begin{array}{c}161 \pm 80 \\
10\end{array}$ & $\begin{array}{c}81 \pm 38 \\
8\end{array}$ & $\begin{array}{c}102 \pm 86 \\
8\end{array}$ & $\begin{array}{c}105 \pm 63 \\
9\end{array}$ & $\begin{array}{c}86 \pm 47 \\
11\end{array}$ \\
\hline 芯 & Artificial feeding & $\begin{array}{c}91 \pm 48 \\
4\end{array}$ & $\begin{array}{c}155 \pm 68 \\
5\end{array}$ & $\begin{array}{c}90 \pm 57 \\
6\end{array}$ & $\begin{array}{c}101 \pm 22 \\
4\end{array}$ & $\begin{array}{c}106 \pm 64 \\
5\end{array}$ & $\begin{array}{c}114 \pm 61 \\
4\end{array}$ \\
\hline $\begin{array}{l}0 \\
\stackrel{0}{0} \\
2\end{array}$ & Breast feeding & $\begin{array}{c}333 \pm 189 \\
10\end{array}$ & $\begin{array}{c}350 \pm 225 \\
11\end{array}$ & $\begin{array}{c}279 \pm 111 \\
14\end{array}$ & $\begin{array}{c}266 \pm 156 \\
12\end{array}$ & $\begin{array}{c}275 \pm 152 \\
15\end{array}$ & $\begin{array}{c}252 \pm 141 \\
6\end{array}$ \\
\hline 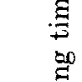 & Mixed feeding & $\begin{array}{c}386 \pm 155 \\
15\end{array}$ & $\begin{array}{c}270 \pm 201 \\
10\end{array}$ & $\begin{array}{c}308 \pm 161 \\
9\end{array}$ & $\begin{array}{c}202 \pm 74 \\
8\end{array}$ & $\begin{array}{c}272 \pm 181 \\
19\end{array}$ & $\begin{array}{c}188 \pm 106 \\
11\end{array}$ \\
\hline 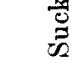 & Artificial feeding & $\begin{array}{c}329 \pm 97 \\
4\end{array}$ & $\begin{array}{c}206 \pm 97 \\
5\end{array}$ & $\begin{array}{c}330 \pm 198 \\
6\end{array}$ & $\begin{array}{c}171 \pm 81 \\
4\end{array}$ & $\begin{array}{c}261 \pm 234 \\
5\end{array}$ & $\begin{array}{c}250 \pm 117 \\
4\end{array}$ \\
\hline $\begin{array}{l}\text { D } \\
.0 \\
.0\end{array}$ & Breast feeding & $\begin{array}{c}275 \pm 198 \\
10\end{array}$ & $\begin{array}{c}244 \pm 112 \\
11\end{array}$ & $\begin{array}{c}230 \pm 82 \\
14\end{array}$ & $\begin{array}{c}215 \pm 114 \\
12\end{array}$ & $\begin{array}{c}216 \pm 105 \\
15\end{array}$ & $\begin{array}{c}184 \pm 99 \\
6\end{array}$ \\
\hline 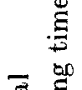 & Mixed feeding & $\begin{array}{c}286 \pm 117 \\
15\end{array}$ & $\begin{array}{c}233 \pm 186 \\
10\end{array}$ & $\begin{array}{c}257 \pm 134 \\
9\end{array}$ & $\begin{array}{c}156 \pm 51 \\
8\end{array}$ & $\begin{array}{c}225 \pm 153 \\
19\end{array}$ & $\begin{array}{c}152 \pm 83 \\
11\end{array}$ \\
\hline$\frac{5}{0}$ & Artificial feeding & $\begin{array}{c}253 \pm 197 \\
4\end{array}$ & $\begin{array}{c}177 \pm 59 \\
5\end{array}$ & $\begin{array}{c}196 \pm 87 \\
6\end{array}$ & $\begin{array}{c}146 \pm 62 \\
4\end{array}$ & $\begin{array}{c}200 \pm 195 \\
5\end{array}$ & $\begin{array}{c}189 \pm 41 \\
4\end{array}$ \\
\hline
\end{tabular}

* Mean value \pm S.D. \& Number of cases

feeding groups were compared with those of the breast-feeding group. The sucking rate in the mixed and artificial groups was not different from those in the breastfeeding group. The intraoral pressure in the artificial and mixed feeding groups was also not different from that of the breast-feeding group (Fig. 2). There was no definite difference in the three time parameters of sucking ability between the groups of different feedings, although some variations in the values obtained were noticed (Table 2).

According to the methods of delivery, the newborns were divided into the groups of spontaneous delivery, cesarean section delivery, vacuum-forceps delivery and breech delivery, and the five parameters of sucking ability in the groups of abnormal delivery were compared with those in the group of spontaneous delivery. The sucking rate seemed to be higher on the whole in the group of vacuum-forceps delivery. In general, however, there was no significant difference in the rate between the normal and abnormal delivery groups. The intraoral pressure in each of the three groups of abnormal delivery did not differ from that in the group of spontaneous delivery (Fig. 3). In the group of vacuum-forceps delivery, the time parameters of sucking did not differ markedly from those in the group of spontaneous delivery after the 4th day. In the group of breech delivery, 


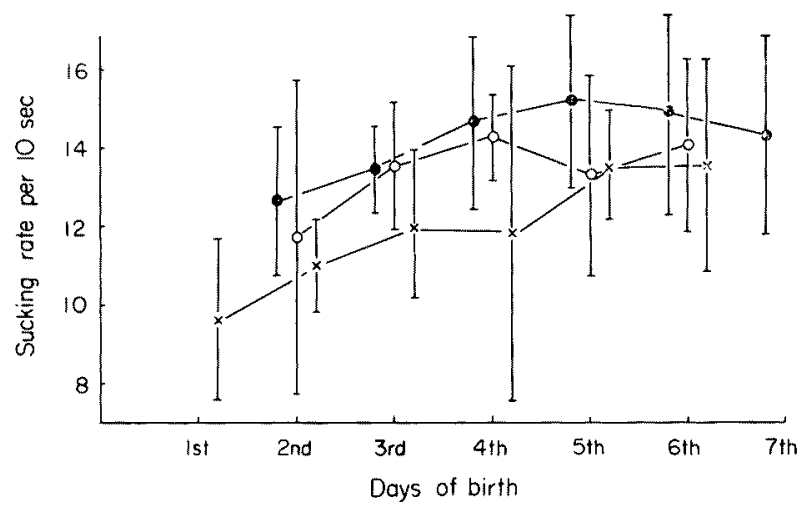

\begin{tabular}{|c|c|c|c|c|c|c|c|c|}
\hline \multirow{2}{*}{$\begin{array}{c}\text { Number } \\
\text { of }\end{array}$} & • & & 8 & 9 & 6 & 6 & 8 & 5 \\
\hline & 0 & & 4 & 4 & 4 & 5 & 4 & \\
\hline cases & $x$ & 5 & 4 & 6 & 6 & 7 & 6 & \\
\hline
\end{tabular}

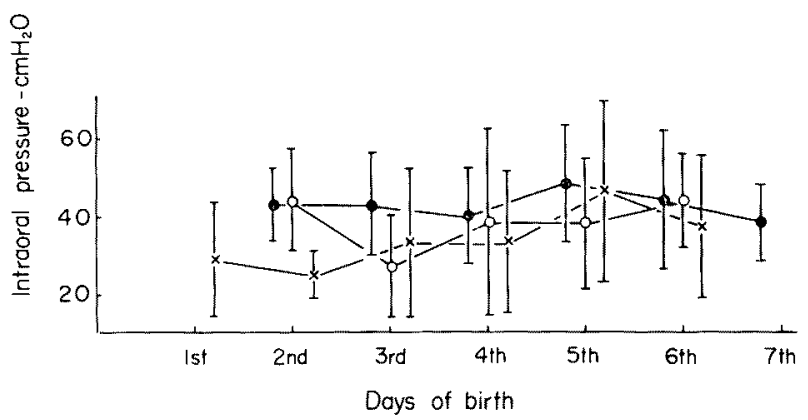

\begin{tabular}{|c|c|c|c|c|c|c|c|c|}
\hline \multirow{2}{*}{$\begin{array}{c}\text { Number } \\
\text { of } \\
\text { cases }\end{array}$} & - & & 8 & 9 & 6 & 6 & 7 & 5 \\
\hline & 0 & & 4 & 4 & 4 & 5 & 4 & \\
\hline & & 5 & 4 & 6 & 6 & 7 & 6 & \\
\hline
\end{tabular}

Fig. 3. Sucking rate and intraoral pressure of vacuum-forceps, breech and cesarean section delivery newborns.

- Vacuum-forceps. o Breech. × Cesarean section.

no difference was detected on the time parameters except that the sucking and actual sucking time was prolonged on the 5th day $(0.02<p<0.05$ for both). In the group of cesarean section delivery, the measurement beginning from the 4th day demonstrated no difference in the time parameters until the 6th day (Table 3).

Daily changes in the sucking ability of the premature newborns of spontaneous delivery with normal weight were shown in Fig. 4 . The sucking rate of the premature newborns increased significantly within one day after birth $0.001<p<$ 0.01 ), but afterwards the rate did not change until the 6th day. In the comparison of the sucking rate between the newborns with premature delivery and those 
TaBLe 3, Continuous sucking time, sucking time and actual sucking time on the 2nd to 7th days of birth of newborns with vacuum-forceps, breech and cesarean section delivery

\begin{tabular}{|c|c|c|c|c|c|c|c|}
\hline & Delivery & 2nd day & 3rd day & 4th day & 5th day & 6th day & 7th day \\
\hline 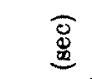 & Vacuum-forceps & $\begin{array}{c}58 \pm 48^{*} \\
5 \dagger\end{array}$ & $\begin{array}{c}84 \pm 55 \\
7\end{array}$ & $\begin{array}{c}194 \pm 186 \\
4\end{array}$ & $\begin{array}{c}117 \pm 96 \\
5\end{array}$ & $\begin{array}{c}97 \pm 61 \\
7\end{array}$ & $\begin{array}{c}92 \pm 42 \\
5\end{array}$ \\
\hline 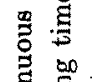 & Breech & & & & $\begin{array}{c}96 \pm 77 \\
4\end{array}$ & $\begin{array}{c}66 \pm 56 \\
4\end{array}$ & \\
\hline ঠુ & Cesarean section & & & $\begin{array}{c}66 \pm 50 \\
6\end{array}$ & $\begin{array}{c}106 \pm 33 \\
8\end{array}$ & $\begin{array}{c}128 \pm 121 \\
6\end{array}$ & \\
\hline 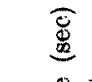 & Vacuum-forceps & $\begin{array}{c}482 \pm 157 \\
6\end{array}$ & $\begin{array}{c}318 \pm 297 \\
7\end{array}$ & $\begin{array}{c}256 \pm 157 \\
4\end{array}$ & $\begin{array}{c}196 \pm 63 \\
5\end{array}$ & $\begin{array}{c}186 \pm 152 \\
7\end{array}$ & $\begin{array}{c}182 \pm 67 \\
5\end{array}$ \\
\hline 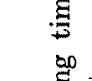 & Breech & & & & $\begin{array}{c}379 \pm 153 \\
4\end{array}$ & $\begin{array}{c}306 \pm 117 \\
4\end{array}$ & \\
\hline 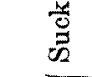 & Cesarean section & & & $\begin{array}{c}499 \pm 331 \\
6\end{array}$ & $\begin{array}{c}283 \pm 140 \\
8\end{array}$ & $\begin{array}{c}348 \pm 150 \\
6\end{array}$ & \\
\hline$\stackrel{8}{\mathscr{8}}$ & Vacuum-forceps & $\begin{array}{c}345 \pm 150 \\
6\end{array}$ & $\begin{array}{c}214 \pm 170 \\
7\end{array}$ & $\begin{array}{c}197 \pm 205 \\
4\end{array}$ & $\begin{array}{c}152 \pm 50 \\
5\end{array}$ & $\begin{array}{c}157 \pm 94 \\
7\end{array}$ & $\begin{array}{c}150 \pm 44 \\
5\end{array}$ \\
\hline 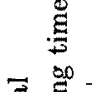 & Breech & & & & $\begin{array}{c}290 \pm 107 \\
4\end{array}$ & $\begin{array}{c}238 \pm 110 \\
4\end{array}$ & \\
\hline 旇 & Cesarean section & & & $\begin{array}{c}401 \pm 271 \\
6\end{array}$ & $\begin{array}{c}237 \pm 116 \\
8\end{array}$ & $\begin{array}{c}272 \pm 146 \\
6\end{array}$ & \\
\hline
\end{tabular}

with fullterm delivery, any significant difference was not demonstrated at all. The intraoral pressure did not vary for from the first till the 6th days. The other parameters of sucking ability of the newborns with premature delivery were compared with those with the fullterm delivery, but no difference was demonstrated (Fig. 4).

According to whether or not the body weight on the 6th day surpassed the birth weight, the mature newborns with spontaneous delivery were divided into two groups. There was no difference in the sucking ability between the two groups (Fig. 5).

The influence of serum bilirubin level on the sucking ability was examined, while the newborns were divided into two groups of above and below $10 \mathrm{mg} / 100 \mathrm{ml}$ of total serum bilirubin, respectively. The sucking rate tended to increase in the group of higher bilirubin level, whereas intraoral pressure was found rather low. The continuous sucking time was not influenced by the total serum bilirubin level. The sucking time and the actual sucking time in the group of high bilirubin levels were sometimes significantly prolonged (Fig. 6).

The sucking rate and the intraroal pressure in breast-feeding were measured from the 3 rd till the 7 th day by inserting a polyethylene tube attached to the 


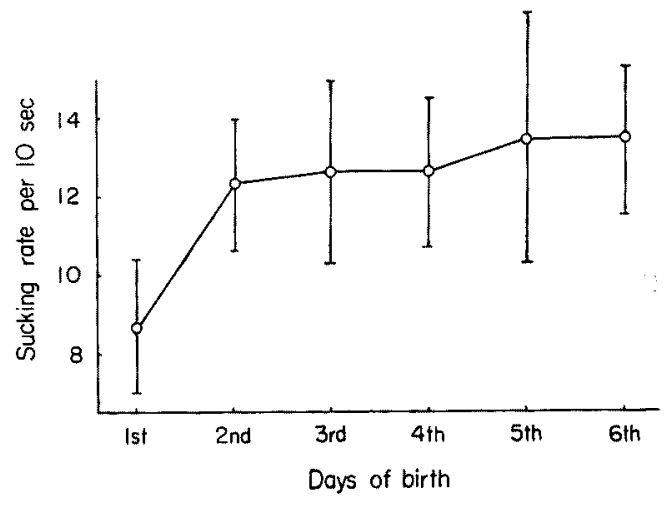

\begin{tabular}{l|l|l|l|l|l|l}
\hline $\begin{array}{l}\text { Number } \\
\text { of cases }\end{array}$ & 5 & 11 & 9 & 10 & 7 & 9
\end{tabular}

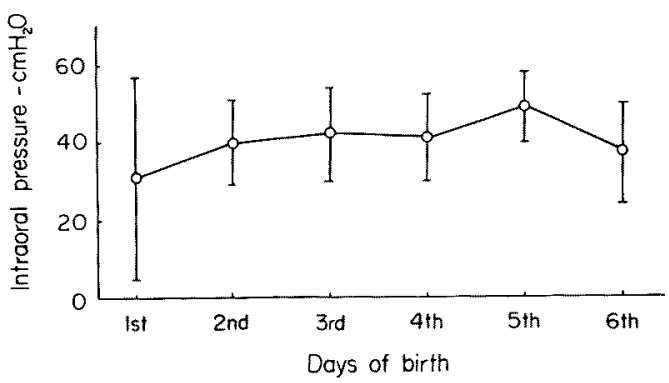

\begin{tabular}{l|l|l|l|l|l|l}
\hline $\begin{array}{l}\text { Number } \\
\text { of cases }\end{array}$ & 5 & 11 & 9 & 10 & 7 & 9
\end{tabular}

\begin{tabular}{l|c|c|c|c|c}
\hline Day after birth & Ist day & 2nd day & 3rd day & 4th day & 5th day \\
\hline $\begin{array}{c}\text { Continuous } \\
\text { sucking time, } \\
\text { sec }\end{array}$ & $\begin{array}{c}6 \pm \pm 29^{*} \\
7 \dagger\end{array}$ & $\begin{array}{c}148 \pm 86 \\
6\end{array}$ & $\begin{array}{c}117 \pm 49 \\
10\end{array}$ & $\begin{array}{c}119 \pm 50 \\
5\end{array}$ & $\begin{array}{c}162 \pm 82 \\
8\end{array}$ \\
\hline $\begin{array}{c}\text { Sucking time, } \\
\text { sec }\end{array}$ & $\begin{array}{c}392 \pm 231 \\
7\end{array}$ & $\begin{array}{c}378 \pm 193 \\
6\end{array}$ & $\begin{array}{c}302 \pm 154 \\
10\end{array}$ & $\begin{array}{c}217 \pm 84 \\
5\end{array}$ & $\begin{array}{c}286 \pm 173 \\
8\end{array}$ \\
\hline $\begin{array}{c}\text { Actual sucking } \\
\text { time, sec }\end{array}$ & $\begin{array}{c}255 \pm 128 \\
7\end{array}$ & $\begin{array}{c}302 \pm 185 \\
6\end{array}$ & $\begin{array}{c}242 \pm 104 \\
10\end{array}$ & $\begin{array}{c}179 \pm 60 \\
5\end{array}$ & $2208 \pm 76$ \\
\end{tabular}

* Mean value +s.d.

$\dagger$ Number of cases

Fig. 4. Five factors of the premature newborns of normal weight.

nipple of the mother into the mouth of newborns. The sucking rate did not vary from the 3rd to 7 th day. The mean intraoral pressure did not vary for from the 3rd till the 7th day (Fig. 7).

In some newborns intraroral pressure rose occasionally for a while during sucking and this pressure elevation made the mother feel pain on the nipple. The levels of this increased pressure were also shown in Fig. 7 in terms of the maximum intraoral pressure. 


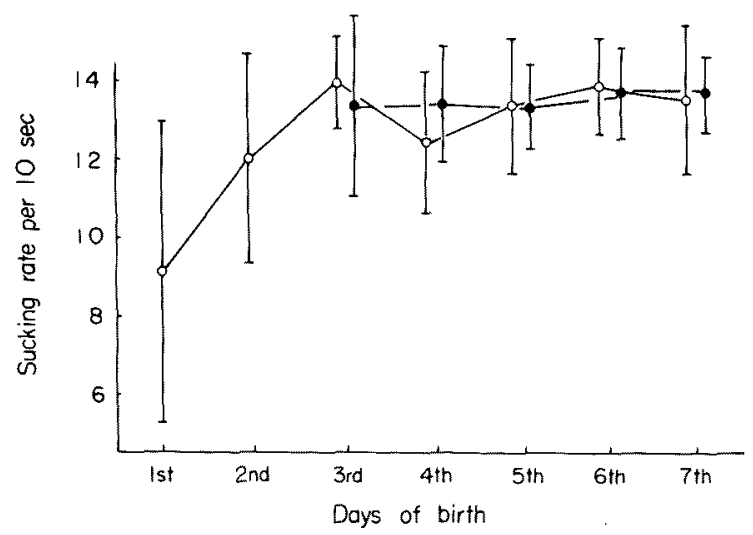

\begin{tabular}{l|r|r|r|r|r|r|r|r}
\hline $\begin{array}{l}\text { Number } \\
\text { of cases }\end{array}$ & 8 & 15 & 14 & 10 & 11 & 9 & 6 \\
\hline
\end{tabular}

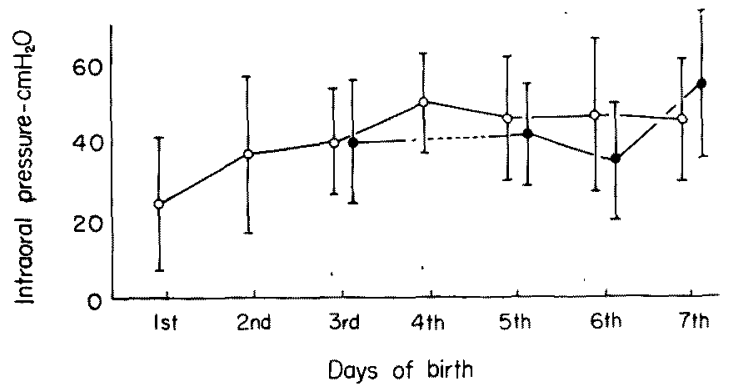

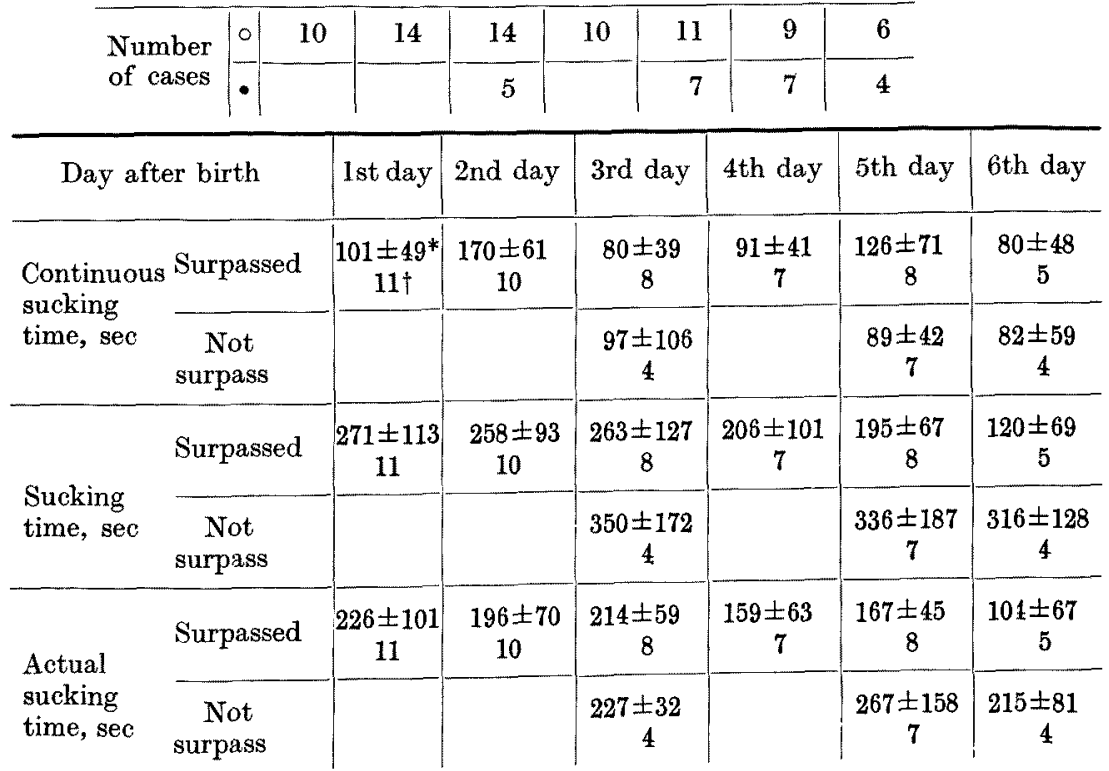

* Mean value \pm S.D.

$\dagger$ Number of cases.

Fig. 5. Five factors on sucking of the newborns whose weight surpassed and did not surpass the birth weight

- Surpassed.

- Not surpass. 


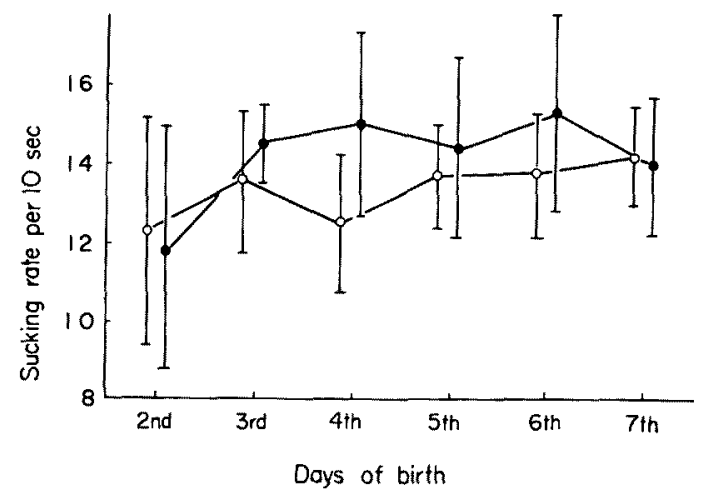

\begin{tabular}{l|r|r|r|r|r|r|r}
$\begin{array}{l}\text { Number } \\
\text { of cases }\end{array}$ & 15 & 19 & 16 & 17 & 19 & 12 \\
\cline { 2 - 6 } & 5 & 6 & 4 & 7 & 6 & 6
\end{tabular}

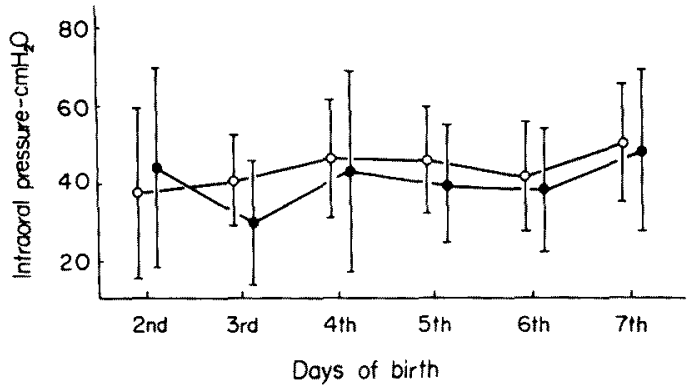

\begin{tabular}{c|c|c|c|c|c|c|c}
\hline $\begin{array}{l}\text { Number } \\
\text { of cases }\end{array}$ & 16 & 19 & 15 & 17 & 19 & 12 \\
\cline { 1 - 3 } & 5 & 6 & 4 & 7 & 6 & 6
\end{tabular}

\begin{tabular}{|c|c|c|c|c|c|c|c|}
\hline \multicolumn{2}{|c|}{ Day after birth } & lst day & 2nd day & 3rd day & 4th day & 5th day & 6th day \\
\hline \multirow{2}{*}{$\begin{array}{l}\text { Continuous } \\
\text { sucking } \\
\text { time, sec }\end{array}$} & Below $10 \mathrm{mg}$ & $\begin{array}{c}115 \pm 53^{*} \\
9^{\dagger}\end{array}$ & $\begin{array}{c}170 \pm 51 \\
10\end{array}$ & $\begin{array}{c}88 \pm 72 \\
15\end{array}$ & $\begin{array}{c}83 \pm 38 \\
11\end{array}$ & $\begin{array}{c}110 \pm 51 \\
18\end{array}$ & $\begin{array}{c}92 \pm 57 \\
12\end{array}$ \\
\hline & Above $10 \mathrm{mg}$ & & & & $\begin{array}{c}64 \pm 39 \\
5\end{array}$ & $\begin{array}{c}62 \pm 45 \\
6\end{array}$ & $\begin{array}{c}50 \pm 27 \\
6\end{array}$ \\
\hline \multirow{2}{*}{$\begin{array}{l}\text { Sucking } \\
\text { time, sec }\end{array}$} & Below $10 \mathrm{mg}$ & $\begin{array}{c}251 \pm 31 \\
9\end{array}$ & $\begin{array}{c}218 \pm 94 \\
10\end{array}$ & $\begin{array}{c}288 \pm 185 \\
15\end{array}$ & $\begin{array}{c}203 \pm 118 \\
11\end{array}$ & $\begin{array}{c}220 \pm 99 \\
16\end{array}$ & $\begin{array}{c}245 \pm 150 \\
12\end{array}$ \\
\hline & Above $10 \mathrm{mg}$ & & & & $\begin{array}{c}266 \pm 194 \\
5\end{array}$ & $\begin{array}{c}476 \pm 247 \\
6\end{array}$ & $\begin{array}{c}231 \pm 86 \\
6\end{array}$ \\
\hline \multirow{2}{*}{$\begin{array}{l}\text { Actual } \\
\text { sucking } \\
\text { time, sec }\end{array}$} & Below $10 \mathrm{mg}$ & $\begin{array}{c}213 \pm 96 \\
9\end{array}$ & $\begin{array}{c}196 \pm 70 \\
10\end{array}$ & $\begin{array}{c}206 \pm 107 \\
15\end{array}$ & $\begin{array}{c}166 \pm 88 \\
11\end{array}$ & $\begin{array}{c}183 \pm 74 \\
18\end{array}$ & $\begin{array}{c}191 \pm 105 \\
12\end{array}$ \\
\hline & Above $10 \mathrm{mg}$ & & & & $\begin{array}{c}190 \pm 110 \\
5\end{array}$ & $\begin{array}{c}387 \pm 223 \\
6\end{array}$ & $\begin{array}{c}177 \pm 69 \\
6\end{array}$ \\
\hline
\end{tabular}

* Mean value \pm s.D.

$\uparrow$ Number of cases

Fig. 6. Five parameters for sucking ability of the newborns whose serum bilirubin levels were below or above $10 \mathrm{mg}$.

- Below $10 \mathrm{mg}$.

- Above $10 \mathrm{mg}$. 

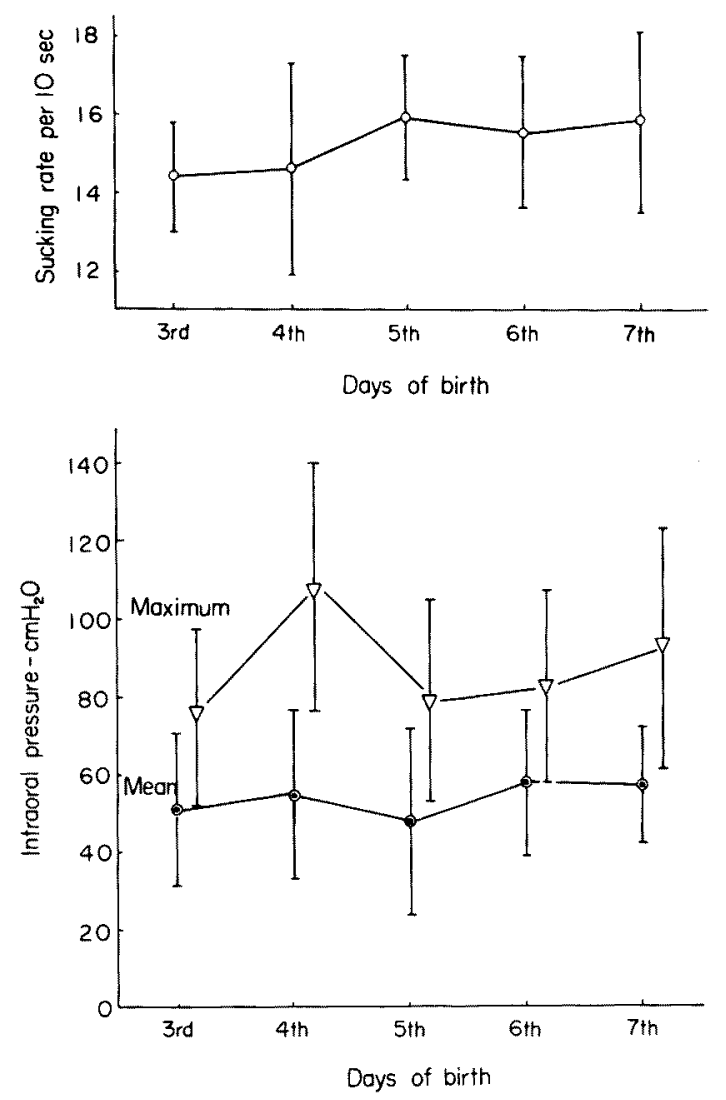

\begin{tabular}{|c|c|c|c|c|c|}
\hline Days after birth & 2nd day & 3 rd day & 4th day & 5 th day & 6 th day \\
\hline $\begin{array}{l}\text { Sucking rate } \\
\text { per } / 10 \mathrm{sec}\end{array}$ & ${ }^{* 14.4 \pm} \underset{7 \dagger}{1.4}$ & $\begin{array}{c}14.0 \pm 2.9 \\
8\end{array}$ & $\begin{array}{c}15.9 \pm 1.6 \\
12\end{array}$ & $\begin{array}{c}15.5 \pm 1.9 \\
17\end{array}$ & $\begin{array}{c}15.8 \pm 2.3 \\
8\end{array}$ \\
\hline $\begin{array}{l}\text { Maximum pressure } \\
\text { in } \mathrm{cm} \mathrm{H}_{2} \mathrm{O}\end{array}$ & $\begin{array}{c}75 \pm 23 \\
7\end{array}$ & $\begin{array}{cc}108 & \pm 32 \\
& 8\end{array}$ & $\begin{array}{cl}79 & \pm 26 \\
12\end{array}$ & $\begin{array}{cl}83 & \pm 25 \\
18\end{array}$ & $\begin{array}{c}93 \pm 31 \\
8\end{array}$ \\
\hline $\begin{array}{l}\text { Mean pressure } \\
\text { in } \mathrm{cm} \mathrm{H}_{2} \mathrm{O}\end{array}$ & $\begin{array}{c}51 \pm 20 \\
7\end{array}$ & $\begin{array}{c}55 \quad \pm 22 \\
8\end{array}$ & $\begin{array}{c}48 \pm 26 \\
12\end{array}$ & $\begin{array}{ll}58 & \pm 19 \\
17\end{array}$ & $\begin{array}{c}57 \pm 15 \\
8\end{array}$ \\
\hline
\end{tabular}

* Mean value or level \pm s.D.

$\uparrow$ Number of cases

Fig. 7. Sucking rate and intraoral pressure during breast feeding.

- Max.: Maximum intraoral pressure.

- Mean: Mean intraoral pressure.

The newborns usually maintained negative intraoral pressure during sucking. However, in some newborns intraoral pressure turned to positive, or was alternately positive-negative for a while. Some temporal parameters of sucking in these newborns differed from those in the newborns with constantly negative intraoral pressure in that the sucking time and actual sucking time were significantly 

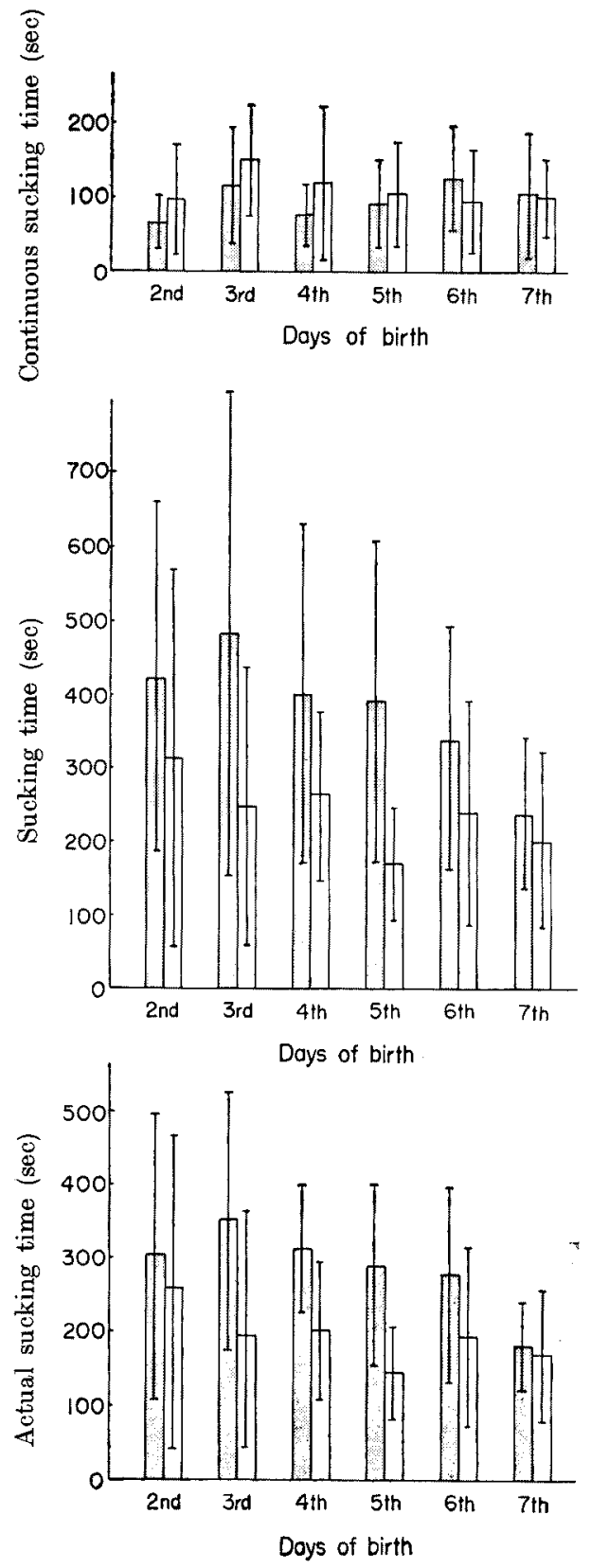

\begin{tabular}{l|l|l|l|l|l|l|l}
\hline \multirow{2}{*}{ Number of cases } & Positive & 13 & 17 & 18 & 18 & 17 & 11 \\
\cline { 2 - 8 } & Negative & 18 & 15 & 23 & 19 & 31 & 18
\end{tabular}

Fig. 8. Continuous sucking time, sucking time and actual sucking time of the newborns who kept their intraoral pressure positive for a while and those who kept the pressure only negative.

跑 Positive $\square$ Negative 


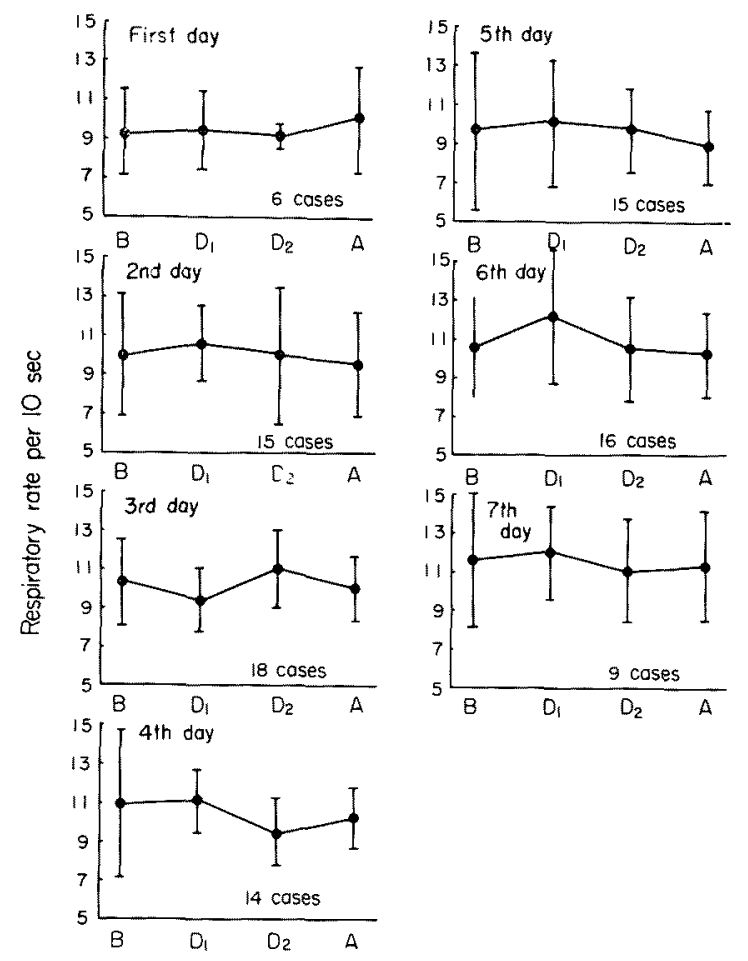

Fig. 9. Respiratory rate of the newborns before, during and after sucking.

B: Before sucking.

$\mathrm{D}_{1}$ : During sucking; from 5 seconds until 15 seconds after beginning of sucking.

$\mathrm{D}_{2}$ : During sucking; from 60 seconds until 70 seconds after beginning of sucking.

A: After sucking.

prolonged on the 3rd to 6th days. Consequently, it became clear that such newborns needed much time for lactation. This prolongation, however, was unrecognizable on the 7th day (Fig. 8).

The respiratory rates during the period of 10 seconds immediately before, during or immediately after sucking are shown in Fig. 9. The rates at each time did not differ significantly. Consequently, it could be concluded that the respiratory rate of newborns was not influenced by sucking. In addition, as the respiratory rate during sucking did not paralleled the sucking rate, it is assumed that during sucking the newborns breathed at a phase different from that of sucking.

\section{Discussion}

Up to the present time, the sucking ability of newborns has mainly been estimated by direct observations. In the present investigation, the sucking ability of normal newborns was analyzed for five parameters i.e., sucking rate, intraoral pressure, continuous sucking time, sucking time and actual sucking 
time. The continuous sucking time and sucking time proved to be very important in the estimation of sucking ability. The longer the continuous sucking time and the shorter the sucking time, the better the sucking ability, because newborns seemed to suck much milk at a draught. All the five parameters of sucking ability could be measured and recorded objectively using the present experimental method.

It was necessary to standardize exactly the experimental conditions. Rubber-nipples of the same size and hardness were selected; a standardized nipple puncture was done to make holes of a uniform aperture and the nipples were fitted on nursing-bottles containing $20 \mathrm{ml}$ of artificial mill. Then, these nipples were placed on an electric breast pump. With such nipples all the amount of milk was exhausted by the pump in $60 \pm 5$ seconds. In order to avoid the sucking reflex in the newborns by stimulation on the lips, the nursing-bottle was fixed to the bed and the head of the newborn was also fixed on a pillow.

The volume of breast milk secreted until the 4th day of puerperium was relatively small and was reported to be $10-40 \mathrm{ml}$ in a day by Morita (1967) and Bartram (1959) or to be $8-52 \mathrm{ml}$ in a day by Miyazaki et al. (1964). Accordingly, the volume of artificial milk used in the present experiments was made to be $20 \mathrm{ml}$, in order to give sufficient amount of milk. The present results did not give a remarkable difference in the sucking ability of the normal newborns for from the 2nd to the 7 th days, and the sucking rate and the intraoral pressure did not change remarkably for 180 seconds after the beginning of sucking.

Selye (1934) reported that the act of sucking maintained the mammary glands of mother rats active secretion for a long period, even when the galactophores were cut and milk could not be secreted. Findlay (1968) also reported that milk secretion at sucking was decreased in the rats by infiltration anesthesia of the nipples. Consequently, sucking stimulus was found to be the most important factor for milk production and secretion. However, the nature of this stimulus have not been yet clarified. Beintema (1968) reported that no sucking or a very weak sucking movement was often observed on the first two days, and a strong and sustained sucking movement from the 4 days of birth in human newborns. Oguni et al. (1963) reported that the intraoral pressure of normal infants increased from the 3rd day of birth, and after the 4th day the pressure maintained an almost constant level of about $45 \mathrm{mmHg}$. In the present results, the level was almost constant from the 2nd day of birth and almost equal to that reproted by Oguni et al.(1963).

The levels of the sucking factors of the 2 nd day, when the milk secretion from the breast of the mother is very scanty, were already almost equal to the levels of the 7th when abundant milk secretion is expected, and the pressure factors also scarcely changed with time from the beginning of sucking until 180 seconds and not influenced by postnatal days. It could be concluded from these results that the main significance of sucking of newborns was to give the nipple an adequate stimulus for production and secretion of milk. Sucking movement is, however, not merely a reflex movement but also controlled by degree of hunger. Accordingly, 
it seemed to be very reasonable for getting good production and secretion of milk that newborn give adequate stimuli to the nipples from the early days of puerperium, when production and secretion of milk are still insufficient.

The differences between breast milk and artificial milk have been pointed out mainly from the nutritional standpoint. However, there was no difference in the sucking ability of infants between the two methods of feeding.

The present results showed that the effects of the different delivery process and total serum bilirubin level on the sucking ability were only transitory. Further, the duration of pregnancy did not influence the sucking ability in the mature newborns. Sucking action, which is thought to be instinctive or fundamental for infants, is kept stable, in spite of considerably different perinatal conditions.

It is sometimes noticed by lactating mothers that their babies take too long time in sucking in spite of vigorous sucking activity. It became clear in the present results that the infants, who kept their intraoral pressure positive or alternately positive-negative for a while during sucking, took significantly long time for sucking. It was difficult to find out these infants from mere observation. Smith (1959) reported that the calves kept their intraroral pressure negative during sucking, and positive pressure developed in the swallow phase. But, this is not likely in the human infants, because they all keep their intraoral pressure negative during sucking.

\section{References}

1) Bartram, J.B. The Textbook of Pediatrics, edited by N. Nelson, W.B. Saunders Co., Philadelphia, 1959, p. 113.

2) Beintema, D.J. Sucking response. In: A Neurological Study of Newborn Infants, C.D.M. 28, Levenham Press Ltd., Suffolk, 1968, p. 113.

3) Findlay, A.L.K. The effect of teat anaesthesia on the milkejection reflex in the rabbit. J. Endocr., 1968, 40, 127-128.

4) Mayer, H.F. Breast feeding in the United States: Extent and possible trend. A survey of 1,904 hospitals with two and a quarter million birth in 1956. Pediatrics, $1958,22,116-121$.

5) Miyazaki, K., Takahashi, E. \& Kawamo, M. Nutrition of newborn infants. Shonika Rinsho (Jap.), 1964, 17, 993-998.

6) Morita, T. Nutrition of newborn infants, In: Metabolism of Newborn Infants (Jap.), edited by T. Matsumura, Igaku Shoin, Tokyo, 1967, p. 155.

7) Oguni, T. Studies on physiology of newborn infants. Nihon Sanka Fujinka Gakkai Zasshi (Jap.), 1963, 15, 755-764.

8) Selye, H. On the nervous control of lactation. Amer. J. Physiol., 1934, 107, 535-538.

9) Smith, V.R. Mechanics of milking. In: Physiology of Lactation, Iowa State University Press, Ames, Iowa, 1959, p. 156. 